\title{
Social profiles - a dialogue tool
}

\author{
Lene Jensen ${ }^{*}$, Birthe Byskov Holm \\ From 5th European Conference on Rare Diseases (ECRD 2010) \\ Krakow, Poland. 13-15 May 2010
}

Rare disease patients and their families often navigate in unknown territory. Even if medical guidelines for their disease exist, they normally do not mention social and educational matters and the public services in these areas are often inadequate. Because the disease is rare, social workers, teachers and care takers have no knowledge of the consequences and necessary support.

Rare Disorders Denmark has developed a tool, Social Profiles, for the dialogue between the rare disease patients and professionals, that

- gives a short description of the diagnosis and its characteristics in lay terms

- provides a check list for relevant support in a life time perspective, for instance:

- Necessary considerations in general, e.g. assistive technology and interior special design

- Special needs of the small child, the taller child and the youngster, e.g. needs for extra resources in day care, special resources at school and special vocational guidance

- Special needs of adults, e.g. special programmes to obtain labour market contact or special housing

- Contact with the relevant patient society

The Social Profiles have been developed in a process involving rare disease patient societies and exist for 15 rare diagnosis, with more to come.

The Social Profiles consist of verified facts only and are published at the website http://www.sjaeldenborger. $\mathrm{dk}$ (meaning: http://www.rarecitizen.dk).

The Social Profiles have been developed within a state funded project of $420.000 €$ over a 4 -year period, also containing

- Upgrading of skills for patient society advisers

- Virtual tool kit for rare patient societies

*Correspondence: lj@sjaeldnediagnoser.dk

Rare Disorders Denmark, Frederiksholms Kanal 2, Copenhagen, DK 11220 K, Denmark
- Raising awareness about rare disease patients in order to avoid stigmatisation

Published: 19 October 2010

doi:10.1186/1750-1172-5-S1-P14

Cite this article as: Jensen and Holm: Social profiles - a dialogue tool.

Orphanet Journal of Rare Diseases 2010 5(Suppl 1):P14.
Submit your next manuscript to BioMed Central and take full advantage of:

- Convenient online submission

- Thorough peer review

- No space constraints or color figure charges

- Immediate publication on acceptance

- Inclusion in PubMed, CAS, Scopus and Google Scholar

- Research which is freely available for redistribution

Submit your manuscript at www.biomedcentral.com/submit
Biomed Central 